\title{
SOIL RESPIRATION IN STANDS OF DIFFERENT TREE SPECIES
}

\begin{abstract}
Jurgita SASNAUSKIENĖ, Institute of Environment and Ecology, Faculty of Forest Sciences and Ecology, Aleksandras Stulginskis University, Studentu str. 11, LT-53361 Akademija, Kaunas distr. Lithuania; jurgita.sasnauskiene@asu.lt (corresponding author)

Nomeda SABIENE், Institute of Environment and Ecology, Faculty of Forest Sciences and Ecology, Aleksandras Stulginskis University, Studentu str. 11, LT-53361 Akademija, Kaunas distr. Lithuania; nomeda.sabiene@ asu.lt

Vitas MAROZAS, Institute of Environment and Ecology, Faculty of Forest Sciences and Ecology, Aleksandras Stulginskis University, Studentu str. 11, LT-53361 Akademija, Kaunas distr. Lithuania; vitas.marozas@asu.It

Laima ČESONIENE், Institute of Environment and Ecology, Faculty of Forest Science and Ecology, Aleksandras Stulginskis University, Studentu str. 11, LT-53361 Akademija, Kaunas distr. Lithuania, laima.cesoniene@asu.lt

Kristina LINGYTE், Institute of Environment and Ecology, Faculty of Forest Science and Ecology, Aleksandras Stulginskis University, Studentu str. 11, LT-53361 Akademija, Kaunas distr. Lithuania, kristina.lingyte@asu.lt
\end{abstract}

Forest ecosystems of different tree species participate actively in climatic and biotic processes, such as photosynthesis, plant and soil respiration, therefore knowledge of soil respiration, especially of $\mathrm{CO}_{2}$ emissions to the atmosphere is of great importance. The aim of the study was to determine soil respiration rate of stands of deciduous (Betula pubescens Ehrh., Quercus robur L.) and coniferous (Larix eurolepis Henry, Thuja occidentalis L.) tree species as well as impact of abiotic (soil temperature, humidity, electrical conductivity, $\mathrm{pH}$ ) and biotic (abundance of undergrowth, shrub, herbs) factors. Measurements of $\mathrm{CO}_{2}$ emissions, temperature, moisture and electrical conductivity were performed in-situ in the stands of different tree species with portable ADC BioScientific LCpro+ system and digital electrochemical device "Wet" (Delta-T). Soil samples were collected for the physicochemical analysis simultaneously. Chemical analysis of soil samples was done at the lab of the Environmental Research of the Aleksandras Stulginskis University by standard methods. Soil respiration was highest in the stand of Thuja occidentalis and lowest in the stand of Betula pubescens. Soil respiration intensity of the tree stands increased as follow: Thuja $<$ Quercus $<$ Larix< Betula. In the coniferous tree stands, the soil respiration was lower on average $27 \%$ comparing to deciduous tree stands. Soil respiration rate increased with increase of herbaceous vegetation cover and temperature. Soil respiration rate was mostly influenced by abundance of herbaceous vegetation ( $\mathrm{r}$ $=0.91)$ of all biotic factors investigated, while soil temperature $(r=0.75)$ of abiotic factors. 60 years old stands of different tree species formed specific conditions what influenced different soil respiration rates.

Keywords: coniferous trees, $\mathrm{CO}_{2}$, deciduous trees, soil, respiration rate.

\section{INTRODUCTION}

Soil respiration is a complex process involving initial soil biota activity; it is residuals and subsequent soil organic matter decomposition resulted by the activity of microorganisms (Vedrova, 1997; Janušienè, 1996). A measure of soil respiration is $\mathrm{CO}_{2}$ emission from soil to atmosphere. Mean rates of $\mathrm{CO}_{2}$ emissions during the growing season vary from 0.3 to $6.7 \mathrm{t} \mathrm{C}$ ha ${ }^{-1}$ per year depending on climatic zones in various soils (Kudeyarov et al., 1995), the $\mathrm{CO}_{2}$ emission from the forest soil in oak forests in the southern forest-steppe zone reaches 5.6-6.7 t of C/ha per year (Mamaev and Molchanov, 2004).

Therefore, even small fluctuations in soil respiration can largely affect atmospheric $\mathrm{CO}_{2}$ concentrations, what have a great impact on the global warming processes. It is estimated that soil $\mathrm{CO}_{2}$ emissions represent $60-90 \%$ of the total ecosystem respiration of the temperate forests (Goulden et al., 1998; Valentini et al., 2000; Law et al., 2001).

Soil respiration is an indicator well-representing soil biological activity and productivity of phytocoenoses (Mina 1927; Karpachevskii, 1981; Feizienè et al., 2010). Soil micro and macro biota, and plant roots produce energy and release $\mathrm{CO}_{2}$ to the atmosphere using oxygen in processes of respiration and organic matter decomposition (Parkin et al., 1996; Machulla, 2003). According to Janušienè (1996), the maximum quantity of the $\mathrm{CO}_{2}$ gas is released at the period of intensive vegetation as the intensity of organic matter mineralization increases simultaneously. Tree species may affect soil respiration due to differences in the quality of litter and specific climatic conditions under the canopy (Borken et al., 2002; Prescott, 2002).

Soil respiration intensity depends on the plant growth conditions. It increases either when air temperature increases or when air temperature decreases and soil moisture increases. (Schlentner and Van Cleve, 1985; Lloyd and Taylor, 1994; Qi et al., 2002; Rey et al., 2002; Reichstein et al., 2002; Feizienè et al., 2012). Air content in the soil depends on its

Copyright (C) 2017 The Authors. Published by Aleksandras Stulginskis University. This is an open-access article distributed under the terms of the Creative Commons Attribution License (CC-BY 4.0), which permits unrestricted use, distribution, and reproduction in any medium, provided the original author and source are credited. 
'structure, porosity, and moisture. The more soil pores are filled with water, the less air is left there. Moreover, water forms an efficient barrier for gas removes, therefore the gases move slower in the wet soil (Rowell, 1994). Soil abiotic and biotic factors may explain most of the spatial variation in soil respiration (Longdoz et al., 2000). However, complex interactions of those factors restrict our understanding of the underlying mechanisms and thus make it harder to accurately predict soil respiration by models (Adachi et al., 2005).

Influence of tree species on soil quality is well known and documented (Hagen-Thorn et al., 2004; Cardelus et al., 2009; Langenbruch, 2012; Marozas et al., 2013, 2014; Čiuldienè et al., 2017). However, knowledge about their influence on soil respiration is limited.

The aim of this study was to determine soil respiration rate of stands of deciduous (Betula pubescens Ehrh., Quercus robur L.) and coniferous (Larix eurolepis Henry., Thuja occidentalis L.) tree species as well as its' correlation with biotic (abundance of undergrowth, shrubs, and herbs ) and abiotic (soil temperature, humidity, electrical conductivity and $\mathrm{pH}$ ) factors.

\section{RESEARCH METHODS}

The investigation was performed in May 2017 in the stands of deciduous (Betula pubescens Ehrh., Quercus robur L.) and coniferous (Larix eurolepis Henry., Thuja occidentalis L.) trees at the stand park of the Aleksandras Stulginskis University, Kaunas distr., Lithuania. Monoculture tree stands were planted 60 years ago at the same soil and climatic conditions of the temperate mixed forests biome. There Endocalcari-Epihypogleic Cambisols with anthropogenic influence dominate. The average annual temperature was $6.0-6.5^{\circ} \mathrm{C}$, and rainfall was 600-650 mm (Juodis et al., 2013).

Biotic factors, such as undergrowth and shrub, moss and grass plants projection cover (percent per $\mathrm{m}^{2}$ were recorded in the area of $10 \mathrm{~m}^{2}$ in the centers of each stand.

Soil respiration $\left(\mu \mathrm{mol} \mathrm{m} \mathrm{m}^{-1}\right.$ ) was measured with portable $\mathrm{CO}_{2}$ analyzer ADC BioScientific LCpro+ System in the randomly selected points. Mean values of soil $\mathrm{CO}_{2}$ emissions were calculated from 10 replicate measurements. Soil moisture $(\%)$, soil temperature $\left({ }^{\circ} \mathrm{C}\right)$, and specific electrical conductivity, $\left(\mu \mathrm{S} \mathrm{cm}{ }^{-1}\right)$ were measured electrochemically with portable instrument „Wet“at a depth of $5 \mathrm{~cm}$. There also soil samples were collected for laboratory analysis. $\mathrm{pH}$ was measured electrochemically according to ISO 10390:2005 at the lab of the Environmental Research of the Aleksandras Stulginskis university.

\section{RESULTS AND DISCUSSION}

Average $\mathrm{CO}_{2}$ emissions from soils measured at the beginning of the active plant vegetation varied from $0,60 \mu \mathrm{mol}$

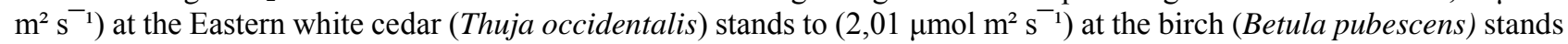
(Table 1). $\mathrm{CO}_{2}$ emissions in the birch and larch stands were significantly $(\mathrm{p}<0.05)$ higher compared to the Eastern white cedar stand. $\mathrm{CO}_{2}$ emissions increased according to the sequence Thuja $<$ Quercus $<$ Larix $<$ Betula. Respiration intensity of the coniferous stands was $27 \%$ lower comparing with the deciduous stands (Table 1). Similar results were presented by Raich and Tufekcioglu (2000) for the same types of soils, just difference was lower (10\%). Weber (1985, 1990) found, that soil respiration intensity in aspen stands in Ontario (Canada) was higher than in the neighbouring Pinus banksiana pine forest. Tewary et al. (1982) observed that soil respiration rate under coniferous trees in Northern India was lower than under deciduous trees in the mixed forests, and this difference was correlated with a lower amount of lignin nitrogen in oak litter. Hudgens and Yavitto (1997) also found higher soil respiration rate in the hardwood forest compared to the nearby pine forest/plantation at New York State (USA). These findings confirm that soil respiration and other properties differ between tree species, but that differences depend not only on soil origin.

Table 1. Soil $\mathrm{CO}_{2}$ emissions under deciduous and coniferous tree stands

\begin{tabular}{|c|c|c|c|c|c|c|}
\hline 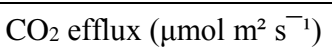 & Valid N & Mean & Minimum & Maximum & Std.Dev. & Coef.Var. \\
\hline deciduous & 20 & $1.51^{\mathrm{ab}}$ & 0.34 & 3.92 & 1.14 & 75.80 \\
\hline coniferous & 20 & $1.10^{\mathrm{b}}$ & 0.35 & 2.06 & 0.60 & 55.10 \\
\hline Betula pubescens Ehrh. & 10 & $2.01^{\mathrm{a}}$ & 0.41 & 3.92 & 1.32 & 65.44 \\
\hline Quercus robur L. & 10 & $1.00^{\mathrm{abc}}$ & 0.34 & 2.13 & 0.76 & 75.29 \\
\hline Larix eurolepis Henry & 10 & $1.59^{\mathrm{a}}$ & 0.99 & 2.06 & 0.39 & 24.63 \\
\hline Thuja occidentalis L. & 10 & $0.60^{\mathrm{c}}$ & 0.35 & 0.78 & 0.22 & 36.55 \\
\hline
\end{tabular}

Our results differed from Raich and Potter (1995) findings. Their didn’t find differences between soil respiration intensity in coniferous and deciduous tree stands which was related to the average monthly temperature. All the publications considered include results from many different locations, also other conditions, like stand age, soil type, moisture conditions, and method of measurement are not taken into account. But it seems that method of measurement have influence on the results. Liang et al. (2004) found that soil respiration intensity in the Tomakomai larch forest was $3.6 \mu \mathrm{mol} \mathrm{m} \mathrm{m}^{-2} \mathrm{~s}^{-1}$ when measured with automated chamber while $3.0 \mu \mathrm{mol} \mathrm{m} \mathrm{m}^{-2} \mathrm{~s}^{-1}$ measured with the open-type chamber. Soil respiration intensity in coniferous forests of Siberia was in the range of 2.8 to $4.1 \mu \mathrm{mol} \mathrm{m} \mathrm{m}^{-2} \mathrm{~s}^{-1}$ (Kelliher et al., 1999) while in the temperate coniferous forest was in the range of 1.0 to $6.5 \mu \mathrm{mol} \mathrm{m}^{-2} \mathrm{~s}^{-1}$ (Law et al. 1999; Xu and Qi, 2001). 
The highest variation $(75.8 \%)$ of soil respiration intensity was observed in the deciduous tree stands, probably due to greater spatial variation resulted by heterogeneity of the plant cover, and uneven distribution of the roots in the soil. Many authors confirm that not only meteorological conditions but also vegetation and coverage have influence for the soil respiration intensity (Raich and Tufekcioglu, 2000).

\section{Influence of the biotic factors on soil respiration intensity}

Vegetation cover has impact on the root respiration and was the main source of the $\mathrm{CO}_{2}$ emissions in-situ (Ryan et al., 1997). Statistical analysis of the results showed that undergrowth and shrub projection cover had moderate but significant negative correlation with soil respiration intensity. Moss and herbs projection cover, in contrary, had strong positive correlation with soil respiration (Fig. 1).
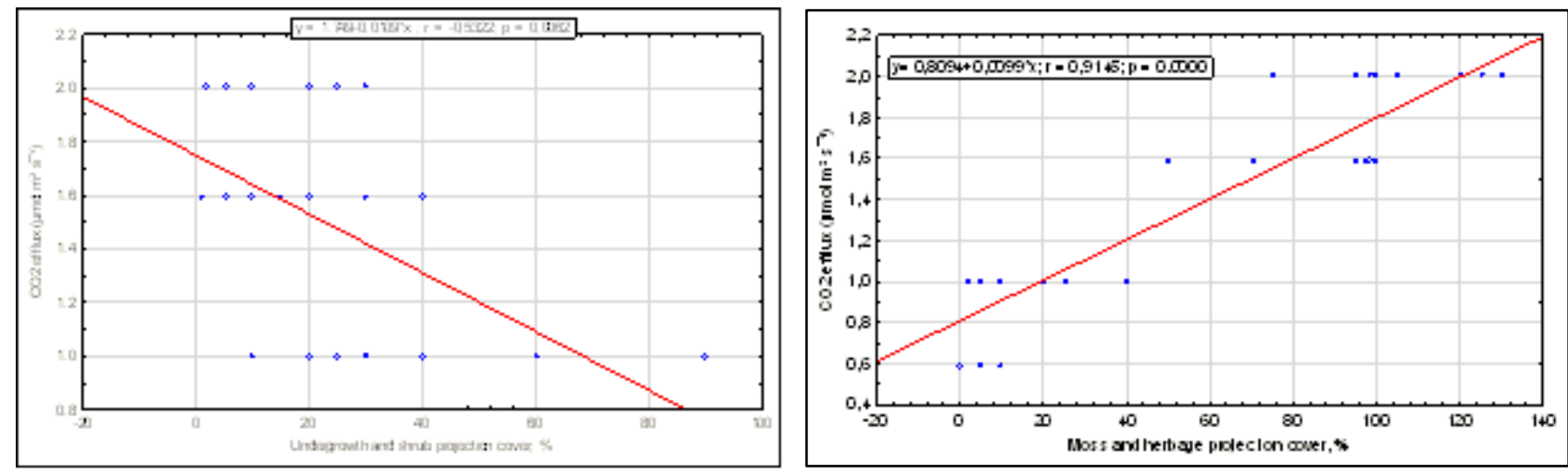

Figure 1. Regression analyses of the plant cover and soil respiration

Undergrowth and shrub projection cover amounted about $0.0-39 \%$ in investigated stands. Therefore to determine influence of the shrub roots on the soil respiration was impossible. It increased in the sequence Thuja $<$ Betula $<$ Larix $<$ Quercus (Table 2). Projection cover of the deciduous tree stands was $48 \%$ higher $(\mathrm{p}<0.05)$ than that of the coniferous. The highest woody plant cover (39\%) was in the oak (Quercus robur) stand, and it was significantly higher than in the birch (Betula pubescens), and larch (Larix eurolepis) stands. In Eastern white cedar (Thuja occidentalis) stand the woody plants were absent.

Table 2. Plant projection cover (undergrowth and shrub, moss and grass) in the stands

\begin{tabular}{|l|c|c|c|c|c|c|}
\hline \multirow{2}{*}{ Species/stand } & \multicolumn{3}{|c|}{ Woody plant cover \% } & \multicolumn{3}{c|}{ Moss and grass cover, \% } \\
\cline { 2 - 7 } & Valid N & Mean & Std.Dev. & Valid N & Mean & Std.Dev. \\
\hline deciduous & 17 & $28.94^{\mathrm{a}}$ & 22.87 & 19 & $56.58^{\mathrm{c}}$ & 49.11 \\
\hline coniferous & 9 & $15.11^{\mathrm{b}}$ & 13.33 & 14 & $65.79^{\mathrm{c}}$ & 42.26 \\
\hline Betula pubescens Ehrh. & 7 & $14.57^{\mathrm{b}}$ & 10.55 & 9 & $104.78^{\mathrm{a}}$ & 17.41 \\
\hline Quercus robur L. & 10 & $39.00^{\mathrm{a}}$ & 24.13 & 10 & $13.20^{\mathrm{d}}$ & 11.84 \\
\hline Larix eurolepis Henry & 8 & $17.00^{\mathrm{b}}$ & 12.90 & 10 & $90.10^{\mathrm{b}}$ & 16.64 \\
\hline Thuja occidentalis L. & - & - & - & 4 & $5.03^{\mathrm{e}}$ & 4.04 \\
\hline
\end{tabular}

Moss and herbs projection cover amounted $5-105 \%$ and increased in the sequence: Thuja $<$ Quercus $<$ Larix $<$ Betula. The most abundant moss and herbs cover (105\%) was in the birch (Betula pubescens) stand. It was significantly higher from other investigated stands. Also, in the coniferous tree stands moss and herbs were higher than that in deciduous, but difference was insignificant. According to Raich and Tufekcioglu (2000), the type of vegetation itself does not affect the soil respiration rate. In some cases, soil respiration was even more intensive in plots without plant cover.

While in some cases influence of the clear cuttings or removal of forest vegetation was insignificant on the annual $\mathrm{CO}_{2}$ emissions (Toland and Zak, 1994; Marra and Edmonds, 1996, Chen et al., 2000). These results support the statement that vegetation type (woody or grass) has relatively little influence on soil respiration rates, but also highlight some of the difficulties in interpreting soil respiration measurements. It is assumed, that influence of the plant cover on the soil respiration was insignificant, but some uncertainties could be due to interpretations of the measurements. Soil respiration is a net flow, produced by several processes, such as respiration of plant roots and various soil organisms, some changes can be hidden (Buyanovsky and Wagner, 1995).

Researchers have long ago noticed that plant cover has an influence on, and that factors often differ among vegetation types (Gates, 1980). Moreover, soil temperature and moisture have a significant influence on soil respiration rates (Lloyd and Taylor, 1994). Therefore the observed differences of soil respiration in different plant communities can often be considered as plant influence on soil microclimate.

\section{Influence of the abiotic factors on soil respiration intensity}

Soil respiration intensity mostly depends on the abiotic factors, such as soil temperature and moisture (Schlentner and Van Cleve, 1985; Carlyle and Then, 1988). Results of the statistical analysis of the data showed that soil temperature 
had a strong positive correlation with $\mathrm{CO}_{2}$ emissions $(\mathrm{r}=0.75)$, and soil moisture had weak positive correlation ( $\left.\mathrm{r}=0.20\right)$. While $\mathrm{pH}$ and electrical conductivity were not related to the $\mathrm{CO}_{2}$ emissions. Moreover trend of the negative relationship was observed (Fig. 2).

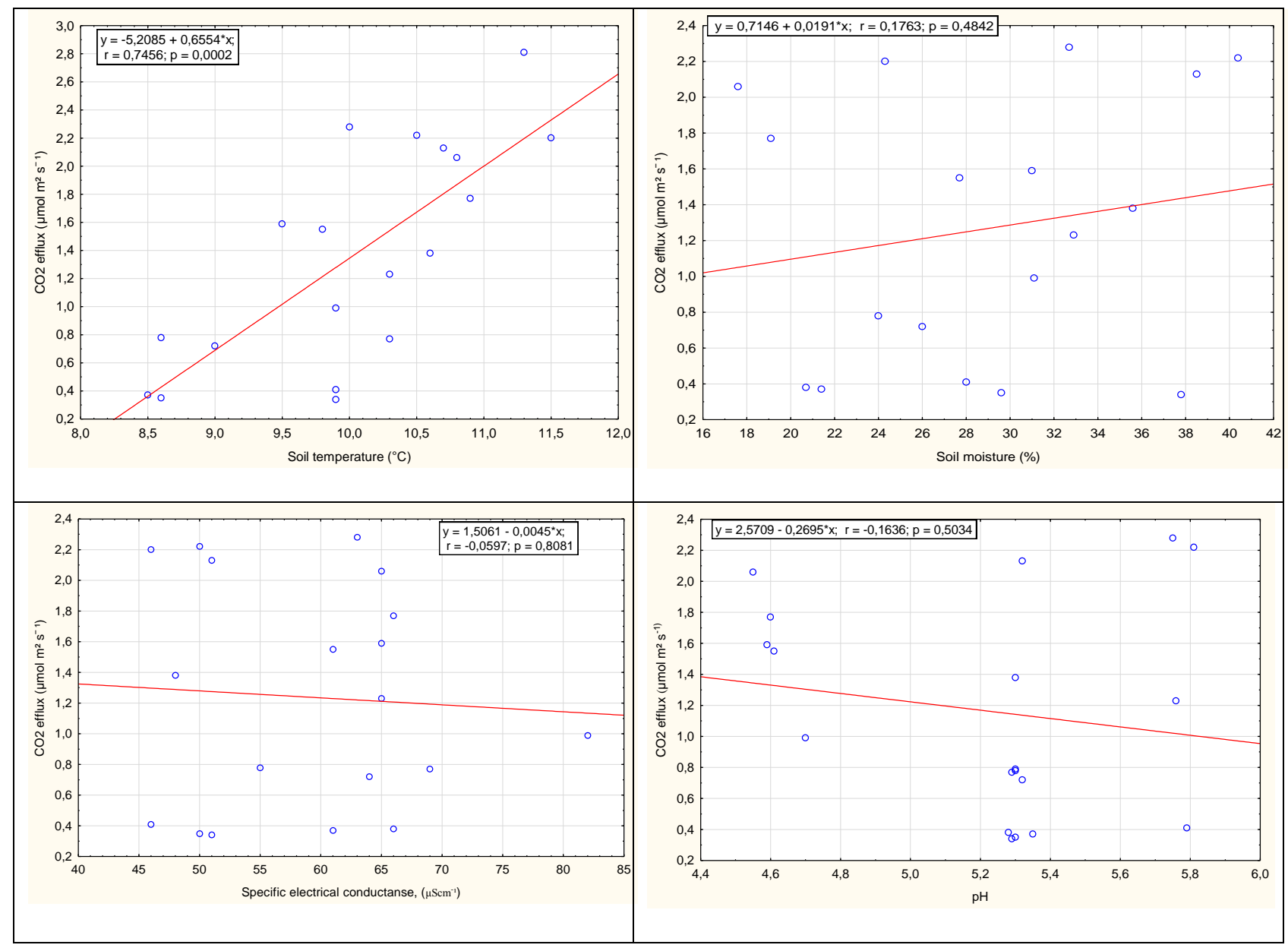

Figure 2. Correlation of the soil respiration rate and abiotic factors

Thus, soil respiration is mostly correlated with the soil temperature. The same findings published Liang et al. (2004). Moreover, Buyanowsky and Wagner (1983) stated that soil temperature influence on the respiration over +15 ${ }^{\circ} \mathrm{C}$. We can see that this trend was at lower temperature. When measurements were conducted, average soil temperature was $+10.17^{\circ} \mathrm{C}$ and varied from $+9,00^{\circ} \mathrm{C}$ (Thuja occidentalis) to $+11,00{ }^{\circ} \mathrm{C}$ (Quercus robur) (Table 3).

Table 3. Abiotic factors of the deciduous and coniferous tree stands

\begin{tabular}{|c|c|c|c|c|c|c|c|c|c|}
\hline \multirow[t]{2}{*}{ Species/stand } & \multirow[t]{2}{*}{ Valid N } & \multicolumn{2}{|c|}{ Soil moisture, $\%$} & \multicolumn{2}{|c|}{ Soil temperature, ${ }^{\circ} \mathrm{C}$} & \multicolumn{2}{|c|}{$\begin{array}{c}\text { Specific electrical } \\
\text { conductance, }\left(\mu \mathrm{Scm}^{-1}\right)\end{array}$} & \multicolumn{2}{|c|}{$\mathrm{pH}$} \\
\hline & & Mean & Std.Dev. & Mean & Std.Dev. & Mean & Std.Dev. & Mean & Std.Dev. \\
\hline deciduous & 10 & $33.06^{\mathrm{a}}$ & 6.76 & $10.74^{\mathrm{a}}$ & 0.75 & $55.2^{\mathrm{bc}}$ & 8.65 & $5.6^{\mathrm{b}}$ & 0.3 \\
\hline coniferous & 10 & $28.25^{\mathrm{ab}}$ & 10.54 & $9.59^{\mathrm{b}}$ & 0.9 & $63.8^{\mathrm{ab}}$ & 8.5 & $5.0^{\mathrm{d}}$ & 0.4 \\
\hline $\begin{array}{l}\text { Betula pubescens } \\
\text { Ehrh. }\end{array}$ & 5 & $34.74^{\mathrm{a}}$ & 5.23 & $10.48^{\mathrm{a}}$ & 0.49 & $58.0^{\mathrm{bc}}$ & 9.3 & $5.8^{\mathrm{a}}$ & 0.2 \\
\hline Quercus robur $\mathrm{L}$. & 5 & $31.38^{\mathrm{ab}}$ & 8.28 & $11.0^{\mathrm{a}}$ & 0.92 & $52.4^{\mathrm{c}}$ & 7.89 & $5.3^{\mathrm{c}}$ & 0.1 \\
\hline $\begin{array}{l}\text { Larix eurolepis } \\
\text { Henry }\end{array}$ & 5 & $25.30^{\mathrm{b}}$ & 6.51 & $10.18^{\mathrm{ab}}$ & 0.63 & $67.8^{\mathrm{a}}$ & 8.17 & $4.6^{\mathrm{e}}$ & 0.1 \\
\hline Thuja occidentalis L. & 5 & $31.20^{\mathrm{ab}}$ & 13.64 & $9.0^{\mathrm{b}}$ & 0.75 & $59.8^{\mathrm{b}}$ & 7.46 & $5.3^{\mathrm{c}}$ & 0.1 \\
\hline
\end{tabular}

abc, different letters show significant differences

According to Buyanowsky and Wagner (1983), the most important factor for $\mathrm{CO}_{2}$ emissions is soil moisture at the temperature over $+10^{\circ} \mathrm{C}$. We found that soil temperature in the coniferous tree stands $\left(9.59^{\circ} \mathrm{C}\right)$ was significantly lower than in deciduous tree stands. Therefore correlation between soil moisture and respiration rate was weak $(\mathrm{r}=0.20)$. It was observed, that low soil moisture $(<19 \%)$ and $\mathrm{CO}_{2}$ emissions had negative correlation while high moisture $(>19 \%)$ had positive correlation with soil respiration (Davidson et al., 1998; Xu and Qi, 2001). Our results confirmed these findings. Average moisture (> $19 \%$ ) had positive correlation with soil respiration rate. This phenomenon was resulted by increasing soil 
microbiological activity related to the increase of soil moisture (Buyanowsky and Wagner, 1983). Liang et al. (2004) found that the most important factor for soil biota activity and plant root respiration was soil temperature at the moisture of 30-40\% in the larch forests at the Hokkaido (Japan). Our results confirm these findings as soil temperature was the main factor $(r=0.75)$ for soil respiration rate when average soil moisture was $30.66 \%$ and varied in the range of 25.30 to $34.74 \%)$.

Soil $\mathrm{pH}$ and electrical conductivity may affect soil respiration as their have strong impact on soil biota, including biomass and population as well as structure and activity of the microorganisms community (Sardinha et al., 2003; Vincent et al., 2006). We did not find correlations between soil electrical conductivity $(\mathrm{r}=-0.10), \mathrm{pH}(\mathrm{r}=-0.20)$ and respiration, nevertheless, some interesting trends were observed. Electrical conductivity varied from 52.40 to $67.80 \mu \mathrm{Scm}^{-1}$. In the coniferous tree stands it was lower than that in the deciduous tree stands, but this difference was insignificant. The highest electrical conductivity was in the larch (Larix eurolepis) stand while in other tree stands it was significantly $(\mathrm{p}<0.05)$ lower.

Soil $\mathrm{pH}$ ranged from 4.6 to 5.8 and also was lower in the coniferous tree stands than that in the deciduous tree stands. It is well known that acidic fulvic acids dominate in the coniferous forests resulting soil acidification as a litter of conifer needles are poorly degradable and humified (Madritch and Cardinale, 2007; Kimmins, 2004; Oulehle et al., 2007). Soil $\mathrm{pH}$ increased in the sequence Larix $<$ Quercus = Thuja $<$ Betula and was significantly higher (5.80) in the birch (Betula pubescens) stand. The same trend was observed in the monoculture tree plantations in Poland (Reich et al., 2005).

In summary, abiotic factors such as soil temperature and moisture as well as their interaction are the main factors influencing soil respiration (Liang et al. 2004). Other factors, such as $\mathrm{pH}$ and electrical conductivity may affect soil respiration through the interactions with other factors, such as soil temperature, moisture, and biota (Rao and Pathak, 1996; Xie JX et al., 2009).

\section{CONCLUSIONS}

1. After 60 years growth four tree species monoculture stands had a different impact on soil respiration which increased in the sequence - Thuja $<$ Quercus $<$ Larix $<$ Betula.

2. Soil respiration rate was about $27 \%$ lower in coniferous tree stands compared with deciduous tree stands.

3. The most important biotic factor for soil respiration increase was moss and herbs cover abundance $(\mathrm{r}=0.91)$.

4. The most important abiotic factor for soil respiration was temperature $(\mathrm{r}=0.75)$.

\section{REFERENCES}

1. Adachi Adachi, M., Bekku, Y.S., Konuma, A., Kadir, W.R., Okuda, T., Koizumi, H. 2005. Required sample size for estimating soil respiration rates in large areas of two tropical forests and of two types of plantation in Malaysia. Forest Ecology and Management, Vol. 210, pp. 455-459.https://doi.org/10.1016/j.foreco.2005.02.011

2. Borken, W., Xu, Y.-J., Davidson, E.A., Beese, F. 2002. Site and temporal variation of soil respiration in European beech, Norway spruce, and Scots pine forests. Global Change Biology, Vol. 8, pp. 1205-1216. https://doi.org/10.1046/j.1365-2486.2002.00547.x

3. Buyanovsky, GA., Wagner, GH. 1995. Soil respiration and carbon dynamics in parallel native and cultivated ecosystems. In: Lal R, Kimble J, Levine E \& Stewart BA (Eds) Soils and Global Change (pp 209-217). CRC Press, Boca Raton, FL, U.S.A.

4. Buyanowski G. A., Wagner G. H. 1983. Annual cycles of carbon dioxide level in soil air. Soil Sciences Society of America Journal, No. 47, pp. 1139-1145

5. Cardelus, C.L., Mack, M.C., Woods, C., DeMarco, J., Treseder, K.K. 2009. The influence of tree species on canopy soil nutrient status in a tropical lowland wet forest in Costa Rica. Plant Soil, Vol. 318, pp. 47-61.https://doi.org/10.1007/s11104-008-9816-9

6. Carlyle, JC \& Than, UB.1988. Abiotic controls of soil respiration beneath an eighteen-year-old Pinus radiata stand in south-eastern Australia. Journal of Ecology, Vol. 76, pp. 654-662. https://doi.org/10.2307/2260565

7. Chen, H., Harmon, M.E., Griffiths, R.P., Hicks, W. 2000. Effects of temperature and moisture on carbon respired from decomposing woody roots. Forest Ecology and Management, Vol. 138, pp. 51-64. https://doi.org/10.1016/S0378-1127(00)00411-4

8. Čiuldienè, D., Aleinikovienè, J., Muraškienė, M., Marozas, V., Armolaitis, K. 2017. Release and Retention Patterns of Organic Compounds and Nutrients after the Cold Period in Foliar Litterfall of Pure European Larch, Common Beech and Red Oak Plantations in Lithuania. Eurasian Soil Science, Vol. 50, pp. 49-56. https://doi.org/10.1134/S1064229316110028

9. Davidson, E. A., Belk, E., Boone, R. D. 1998. Soil water content, and temperature as independent or confounded factors controlling soil respiration in a temperate mixed hardwood forest. Global Change Biology, Vol. 4, $217-227$. https://doi.org/10.1046/j.1365-2486.1998.00128.x

10. Edwards, NT \& Ross-Todd, BM. 1983. Soil carbon dynamics in a mixed deciduous forest following clear-cutting with and without residual removal. Soil Science Society of America Journal, Vol. 47, pp. $1014-1021$. https://doi.org/10.2136/sssaj1983.03615995004700050035x

11. Feizienè, D., Feiza V., Kadžienė, G., Vaideliené, A., Povilaitis, V., Deveikyte, I. 2012. CO2 fluxes and drivers as affected by soil type, tillage and fertilization. Acta Agriculturae Scandinavica Section B - Soil and Plant Science, Vol. 62, Iss. 4, pp. 311-328.

12. Feizienè, D., Feiza, V., Vaidelienè, A., Povilaitis, V., Antanaitis, Š. 2010. Soil surface carbon dioxide exchange rate as affected by soil texture, different long-term tillage application and weather. Zemdirbyste-Agriculture, No. 3, pp. 25-42.

13. Goulden, M.L., Wofsy, S.C., Harden, J.W., Trumbore, S.E., Crill, P.M., Gower, S.T., Fries, T., Daube, B.C., Fan, S.-M., Sutton, D.J., Bazzaz, A., Munger, J.W. 1998. Sensitivity of boreal forest carbon balance to soil thaw. Science, Vol. 279, $214-217$. https://doi.org/10.1126/science.279.5348.214 


\section{Proceedings of the $8^{\text {th }}$ International Scientific Conference Rural Development 2017}

14. Hagen-Thorn, A., Callesen, I., Armolaitis, K., Nihlgard. 2004. The impact of six European tree species on the chemistry of mineral topsoil in forest plantations on former agricultural land. Forest Ecology and Management, Vol. 195, pp.373-384. https://doi.org/10.1016/j.foreco.2004.02.036

15. Hudgens, E \& Yavitt, JB. 1997. Land-use effects on soil methane and carbon dioxide fluxes in forests near Ithaca, New York. Ecoscience, Vol. 4, pp. 214-222. https://doi.org/10.1080/11956860.1997.11682398

16. Janušienè, V. 1996. Herbicidų įtaka dirvožemio kvèpavimo intensyvumui ir agrocheminèms savybèms. Zemdirbyste-Agriculture. Vol. 55, pp. 56. [In Lithuanian]

17. Juodis, J., Lukšienè, L., Šutinienè, L. 2013. Lietuvos nacionalinio atlaso žemėlapis - Dirvožemio danga pagal FAO klasifikaciją. Nacionalinè žemės tarnyba prie Žemès ūkio ministerijos. [In Lithuanian]

18. Karpachevskii, L. O., Forest and Forest Soils (Lesnaya promyshl., Moscow, 1981) [in Russian].

19. Kelliher, F.M., Lloyd, J., Arneth, A., Luhker, B., Byers, J.N., McSeveny, T.M., Milukova, I., Grigoriev, S., Panfyorov, M., Sogatchev, A., Varlargin, A., Ziegler, W., Bauer, G., Wong, S.-C., Schulze, E.-D. 1999. Carbon dioxide efflux density from the floor of a central Siberian pine forest. Agricultural and Forest Meteorologyis, Vol. 94, pp. 217-232. https://doi.org/10.1016/S01681923(99)00014-3

20. Kimmins, J.P. 2004 Forest ecology: a foundation for sustainable forest management and environmental ethics in forestry. 3rd edn. Pearson Prentice Hall, 720 pp. https://doi.org/10.1002/9780470995242.ch2

21. Kudeyarov V. N., Khakimov F. I., Deeva N. F., Il'ina A. A., Kuznetsova T. V., and Timchenko A. V. 1995. Assessment of the respiration of Russian soils. Pochvovedenie, Iss. 1, pp. 33-42.

22. Langenbruch, C., Helfrich, M., Flessa, H. 2012. Effects of beech (Fagus sylvatica), ash (Fraxinus excelsior) and lime (Tilia spec.) on soil chemical properties in amixed deciduous forest. Plant Soil. Vol. 352, pp. 389-403. https://doi.org/10.1007/s11104-011$\underline{1004-7}$

23. Law, B.E., Kelliher, F.M., Baldocchi, D.D., Anthoni, P.M., Irvine, J., Moore, D., Van Tuyl, S. 2001. Spatial and temporal variation in respiration in a young ponderosa pine forest during a summer drought. Agricultural and Forest Meteorologyis, Vol. 110, pp, 27-43. https://doi.org/10.1016/S0168-1923(01)00279-9

24. Liang N., Nakadai T., Hirano T., Qu L., Koike T., Fujinuma Y., Inoue G. 2004. In situ comparison of four approaches to estimating soil CO2 efflux in a northern larch (Larix kaempferi Sarg.) forest. Agricultural and Forest Meteorology, Vol. 123, No. 1-2, pp. 97117. https://doi.org/10.1016/j.agrformet.2003.10.002

25. Lloyd, J., Taylor, J. A. 1994. On the temperature dependence of soil respiration. Functional Ecology, Vol. 8, pp. 315-323. https://doi.org/10.2307/2389824

26. Longdoz, B., Yernaux, M., Aubinet, M. 2000. Soil CO2 efflux measurements in a mixed forest: impact of chamber disturbances, spatial variability and seasonal evolution. Global Change Biology, Vol. 6, pp. 907-917.https://doi.org/10.1046/j.13652486.2000.00369.x

27. Machulla, G. 2003. Soil microbial indicators and their environmental significance. Journal of Soils and Sediments, 3 , p.229. https://doi.org/10.1007/BF02988663

28. Madritch, MD., Cardinale, BJ. 2007. Impacts of tree species diversity on litter decomposition in northern temperate forests of Wisconsin, USA: a multi-site experiment along a latitudinal gradient. Plant and Soil, Vol. 292, No. 1, pp. 147-159. https://doi.org/10.1007/s11104-007-9209-5

29. Mamaev, V. V., Molchanov, A. G. 2004. The depen dence of CO2 emission from the soil surface on the environmental factors in oak groves of the southern for eststeppe zone. Lesovedenie, No. 1, pp. 56-67.

30. Marra, J.L., Edmonds, R.L. 1996. Coarse woody debris and soil respiration in a clearcut on the Olympic Peninsula, Washington, USA. Can. Journal of Forest Research, Vol. 26, pp. 1337-1345. https://doi.org/10.1139/x26-149

31. Marozas, V., Armolaitis, K., Aleinikovienè, J. 2013. Changes of ground vegetation, soil chemical properties and microbiota following the surface fires in Scots pine forests. Journal of Environmental Engineering and Landscape Management, Vol. 21: pp. 67-75.https://doi.org/10.3846/16486897.2012.663087

32. Marozas, V., Augustaitis, A., Armolaitis, K., Kliučius, A., Pilkauskas, M. 2014. Effects of planted European beech on the understory in Scots pine forests of Lithuania. iForest-Biogeosciences and Forestry, Vol.7, pp. 12-18. https://doi.org/10.3832/ifor0695-007

33. Mina V. N. 1957.Biological activity of forest soils in dependence on the physiographic factors and the composition of tree stands. Pochvovedenie, No. 10, pp. 73-79.

34. Oulehle, F, Hofmeister, J., Hruska, J. 2007. Modelling of the long - term effect of tree species (Norway spruce and European beech) on soil acidification in the Ore Mountains. Ecological Modelling, Vol. 204, pp. 359-371.

35. Parkin, T. B, Doran, J. W., Franco-Vizcaino, E. 1996. Field and laboratory tests of soil respiration. pp.231-246. In: J.W. Doran and A.J. Jones (eds.) Methods for assessing soil quality. Soil Sci.Soc. Am. Spec. Publ. 49. SSSA, Madison, WI.410.

36. Prescott, C.E., 2002. The influence of the forest canopy on nutrient cycling. Tree Physiol, Vol. 22, 1193-1200. https://doi.org/10.1093/treephys/22.15-16.1193

37. Qi Y., Xu, M., Wu, J. 2002. Temperature sensitivity of soil respiration and its effects on ecosystem carbon budget: nonlinearity begets surprises. Ecological Modelling, Vol. 153, pp. 131-142. https://doi.org/10.1016/S0304-3800(01)00506-3

38. Raich, JW., Potter, CS. 1995. Global patterns of carbon dioxide emissions from soils. Global Biogeochem, No. 9, pp. $23-36$. https://doi.org/10.1029/94GB02723

39. Raich, J.W., Tufekcioglu, A., 2000. Vegetation and soil respiration: correlations and controls. Biogeochemistry, Vol. 48, pp. 71-90. https://doi.org/10.1023/A:1006112000616 


\section{Proceedings of the $8^{\text {th }}$ International Scientific Conference Rural Development 2017}

40. Rao, DLN., Pathak, H. 1996. Ameliorative influence of organic matter on biological activity of salt affected soils. Arid Soil Research and Rehabilitation, Vol. 10, pp. 311-319. https://doi.org/10.1080/15324989609381446

41. Reich, P. B., Oleksyn, J., Modrzynski, J., Mrozinski, P., Hobbie, S. E., Eissenstat, D. M., Jon Chorover, Chadwick, O. A., Hale C. M., Tjoelker M. G. 2005. Linking litter calcium, earthworms and soil properties: a common garden test with 14 tree species. Ecology Letters, Vol. 8, pp. 811-818 p.

42. Reichstein, M., Tenhunen, J. D., Roupsard, O., Ourcival, J. M., Rambal, S., Dore, S. and Valentini, R. 2002. Ecosystem respiration in two Mediterranean evergreen Holm Oak forests: drought effects and decomposition dynamics. Functional Ecology, Vol. 16, pp. 27-39. https://doi.org/10.1046/j.0269-8463.2001.00597.x

43. Rey, A., Pegoraro, E., Tedeschi, V., De Parri, I., Jarvis, P. G., Valentini, R. 2002. Annual variation in soil respiration and its components in a coppice oak forest. Global Change Biology, Vol. 8, pp. 851-866. https://doi.org/10.1046/j.1365$\underline{\text { 2486.2002.00521.x }}$

44. Ryan, MG, Lavigne, MG., Gower, ST. 1997. Annual carbon cost of autotrophic respiration in boreal forest ecosystems in relation to species and climate. Journal of Geophysical Research, Vol. 102(D24), pp. 28,871-28,883. https://doi.org/10.1029/97JD01236

45. Rowell, D. L. 1994. Soil Science: Methods and application. Departament of Science. Longman. pp. 24-279.

46. Sardinha, M., Müller T., Schmeisky, H., Joergensen, RG. 2003. Microbial performance in soils along a salinity gradient under acidic conditions. Applied Soil Ecology, Vol. 23, pp. 237-244. https://doi.org/10.1016/S0929-1393(03)00027-1

47. Schlentner, R. E., Van Cleve, K. 1985 Relationships between CO2 evolution from soil, substrate temperature, and substrate moisture in four mature forest types in interior Alaska. Canadian Journal of Forest Research, Vol. 15, pp. 97-106. https://doi.org/10.1139/x85-018

48. Singh, JS., Gupta, SR. 1977. Plant decomposition and soil respiration in terrestrial ecosystems. The Botanical Review, Vol. 43, pp. 449-529. https://doi.org/10.1007/BF02860844

49. Tewary, CK., Pandey, U., Singh, JS. 1982. Soil and litter respiration rates in different microhabitats of a mixed oak-conifer forest and their control by edaphic conditions and substrate quality. Plant Soil, Vol. 65, pp. 233-238. https://doi.org/10.1007/BF02374653

50. Toland, DE., Zak, DR. 1994. Seasonal patterns of soil respiration in intact and clear-cut northern hardwood forests. Canadian Journal of Forest Research, Vol. 24, pp. 1711-1716. https://doi.org/10.1139/x94-221

51. Valentini, R., Matteucci, G., Dolman, A.J., Moors, E.J., Granier, A., Gross, P., Jensen, N.O., Pilegaard, K., Lindroth, A., Grelle, A., Bernhofer, C., Grünwald, T., Aubinet, M., Ceulemans, R., Kowalski, A.S., Vesala, T., Rannik, Ü., Berbigier, P., Loustau, D., Guomundsson, J., Thorgeirsson, H., Ibrom, A., Morgenstern, K., Clement, R., Moncrieff, J., Montagnani, L., Minerbi, S., Jarvis, P.G. 2000. Respiration as the main determinant of carbon balance in European forests. Nature, Vol. 404, pp. 861-865. https://doi.org/10.1038/35009084

52. Vedrova, E. F. 1997. Organic matter decomposition in forest litters. European Journal of Soil Science, Vol. 30, Iss. 2, pp. $181-188$.

53. Vincent, B., Marlet, S., Vidal, A., Bouarfa, S., Wu, J., Yang, J., N'Diaye, MK., Kuper, M., Zimmer, D. 2006. Water and soil salinity management and salt redistribution in irrigation systems. In: Combating global soil and land degradation IV. Salinization, sodification and other forms of degradation in agricultural and native ecosystems. Proceeding 18th World Congress of Soil Science, Philadelphia, PA, USA. July 9-15.

54. Weber, MG. 1985. Forest soil respiration in eastern Ontario jack pine ecosystems. Canadian Journal of Forest Research, Vol. 15, pp. 1069-1073. https://doi.org/10.1139/x85-174

55. Weber, MG. 1990. Forest soil respiration after cutting and burning in immature aspen ecosystems. Forest Ecology and Management, Vol. 31, pp. 1-14. https://doi.org/10.1016/0378-1127(90)90107-M

56. Xie, JX., Li, Y., Zhai, CX., Li, CH., Lan, ZD. 2009. CO2 absorption by alkaline soils and its implication to the global carbon cycle. Environmental Geology, Vol. 56, pp. 953-961. https://doi.org/10.1007/s00254-008-1197-0

57. Xu, M., Qi, Y. 2001. Soil-surface CO2 efflux and its spatial and temporal variations in a young ponderosa pine plantation in northern California. Global Change Biology, Vol. 7, pp. 667-677. https://doi.org/10.1046/j.1354-1013.2001.00435.x 